\title{
Analysis of Common Errors in Financial English-Chinese Translation
}

\author{
Chunqian Huang \\ Xi'an Shiyou University, Xi'an, China \\ Email: 851926809@qq.com
}

How to cite this paper: Huang, C.Q. (2021) Analysis of Common Errors in Financial English-Chinese Translation. Open Access Library Journal, 8: e7095. https://doi.org/10.4236/oalib.1107095

Received: December 18, 2020

Accepted: January 11, 2021

Published: January 14, 2021

Copyright $\odot 2021$ by author(s) and Open Access Library Inc.

This work is licensed under the Creative Commons Attribution International License (CC BY 4.0).

http://creativecommons.org/licenses/by/4.0/

\begin{abstract}
As English for a special purpose, financial English is characterized by its strong professionalism and complex sentence structure, thus leading to many translation mistakes. This paper first introduces the stylistic features of financial English, then points out three common mistakes in financial translation with some corresponding examples. At last, three strategies are being put forward for improving the translation quality of financial English, aiming to promote the effective communication between international finance and foreign trade industries.
\end{abstract}

\section{Subject Areas}

Linguistics, Translation

\section{Keywords}

Financial English, Translation, Strategy, Error Analysis

\section{Background Introduction}

With the deepening trend of economic globalization and international financialization, financial English is playing an increasingly important role in international community. However, most financial English news and information are written in English, so the demand for financial English translation in China is gradually increasing. Due to the lack of correct translation skills and encyclopedic information of the source language, there will be a large number of mistranslations and invalid translations, which bring difficulties to readers and make global cooperation and communication more difficult. As such, this paper analyzes the common translation errors in financial English translation, and proposes corresponding strategies based on its stylistic features of financial English. 


\section{Features of Financial English}

This part will talk about some features of financial English from lexical and syntactic perspectives.

\subsection{Lexical Features of Financial English}

There are three types of financial English words [1]. The first one is professional term. For example, “Net interest spread” should be translated into “净利息差” in financial English. "Net Fee and Commission Income" shall be translated into “手续费及佣金净收入”; “Net Profit” should be translated into “净利润”; “Share Capital” shall be translated into “股本”; “Net Capital Base” should be translated into “总资本净额”; “Risk-weighted Assets” should be translated into “风险加权 资产”.

The second is that common words have special meanings in the financial field [2]. For example, “Margin” should be translated into “保证金” in financial English. “Derivatives” shall be translated into “衍生金融工具”; “Listed” should be translated into “上市的”; “Compliance” shall be translated into “合规”; “Balance” should be translated into “余额” in financial English.

The third is frequent use of abbreviations. For example, "NPLs" means "non-performing loans"; "RAROC" refers to "risk-adjusted return on capital"; "VaR" refers to "value at risk"; "RACA" refers to "Risk and Control Assessment"; "KRI” refers to "Key Risk Indicators".

\subsection{Syntactic Features of Financial English}

\subsubsection{Frequent Use of Passive Voice}

As an English for special purpose, financial English uses rigorous and logical words [3]. Therefore, the language should be as objective as possible, and the passive voice just meets this point. The passive voice can make the sentence more compact and logical, so the passive voice is widely used in long financial English sentences.

Example 1: Stress testing for credit risk can be conducted on individual loans and concentrations or other portfolio segments.

Target language: 可以针对单项贷款、集中度或其他细分贷款组别开展信贷 风险压力测试。

Example 2: Audits should be done at least annually and whenever models are revised or replaced.

Target language: 至少每年或在模型修正或更换后开展一次审计。

Analysis: In the examples of 1 and 2, the source language uses the passive voice to indicate the objectivity of the event. In the source language, the word “can be conducted" and “should be done" are translated into “可以开展” and “开展” respectively, which conforms to the expression mode of target language.

\subsubsection{Frequent Use of Clauses}

There are many clauses in financial English. For one thing, due to the emphasis of hypotaxis in English, [4] complex sentence patterns are often used to show the 
logical relationship, making the logic more compact; For another thing, financial English needs to extend the concept and connotation with the help of clauses due to its professionalism and complexity.

Example 3: Similarly, consumer portfolios that are securitized (e.g., mortgages, credit cards, home equity loans) are heavily stress tested during the structuring process to better gauge their risk and to determine the level of credit enhancements.

Target language: 同理, 在构造过程中会对证券化的消费贷款组合(比如, 抵 押贷款、信用卡、房屋净值贷款)进行密集压力测试, 以便更好计量风险和确 定信用增级水平。

Analysis: In example 3, there is an attributive clause to modify the noun "consumer portfolios" and the translation version has adopted proper strategies.

Example 4: While many banks use complex interest rate risk and consumer credit models that take into account the interrelationships between many variables simultaneously, less sophisticated testing methods can also be useful.

Target language: 虽然不少银行使用复杂的利率风险和消费信贷模型(同时 考虑许多变量的相互关系), 但不那么复杂的测试方法可能也很实用。

Analysis: In example 4, there is an attributive clause to explain the "consumer credit models". It means that consumer credit models will take into account many variables. By using attributive clause, the sentence logic seems to be more accurate.

\subsubsection{Frequent Use of Nominal Phrases}

Nominal phrases are often used as an adjunct to explain the context of something or other less important elements. This kind of structure often plays the role of clauses and can avoid the use of subject-predicate structure too much, thus making the writing concise, objective and exact.

Example 5: Banks of all sizes will benefit by supplementing stress testing of individual loans with portfolio stress testing.

Target language: 以贷款组合压力测试补充单项贷款压力测试对大小银行 皆有好处。

Analysis: We use the postpositive attribute "by supplementing stress testing of individual loans" and "with portfolio stress testing" to explain how these two forms benefit banks. The translation version is simple and expressive.

\section{Common Errors in Financial English-Chinese Translation}

There are mainly three types of common errors in financial English-Chinese translation, namely, error of terms, errors of logic analysis and deviation from express mode of target language. More details will be shown in the following part.

\subsection{Errors of Terms}

Financial English belongs to science and technology English, which is rational, complex, logical and compact. Therefore, errors of terms are frequently occurred 
in the process of translation.

Example 6: Asset quality reviews can be used to draw conclusions about underwriting practices, compliance with policy, loan administration, the accuracy of loan information systems, the adequacy of financial and collateral documentation, and the effectiveness of loan control functions.

Version 1: 资产质量审查可以用来得出有关承销实践、遵守政策、贷款管 理、贷款信息系统的准确性、财务和担保文件的充分性以及贷款控制功能的 有效性的结论。

Version 2: 资产质量审查可用于得出以下方面的结论：承贷实践、政策合 规、贷款行政管理、贷款信息系统准确度、财务和抵押品文件充足性以及贷 款控制职能有效性。

Analysis: there are many term mistakes in version 1. "underwriting practices" should be translated into “承贷实践” rather than “承销实践” in this sentence. “Compliance” is always translated into “合规” rather than “遵守” in financial English.

Therefore, attention should be paid to the verification of terms with the help of dictionaries, corpus and parallel texts in the translation of financial English, so as to avoid mistranslation.

\subsection{Errors of Logic Analysis}

The structure of long sentences in financial English is complex. Before translation, it is necessary to divide the sentence structure, make clear the main body and other modifiers. Then, we can accurately grasp the main idea of the sentence and translate it according to the logical sequence of sentences, so as to avoid mistranslation [5].

Example 7: Any reference to an English legal term for any action, remedy, method of judicial proceeding, legal document, legal status, court, official or any legal concept or thing shall, in respect of any jurisdiction other than England, be deemed to include a reference to that which most nearly approximates to the English legal term in that jurisdiction.

Version 1: 提及任何行动的英国法律术语: 救济、司法程序、法律文书、 法律地位、法院、官员或任何法律概念或事物，应当在尊重英格兰以外的任 何管辖权，包括引用的大部分几乎接近英语法律术语的管辖权。

Version 2: 本协议中提及的任何与诉讼、救济、司法程序、法律文件、法 律地位、法院、官员或任何法律概念或事项相关的英国法律术语, 在英国之 外的管辖区, 应被视为指该管辖区内与该英国法律术语含义最为接近的术语。

Analysis: In this example, there are a lot of terms and the sentence is complex. However, there are a lot of mistakes in the translation of version 1 . First of all, it is a legal agreement and should be expressed in formal legal terms. The last two sentences translated in version 1 are misunderstood. So, readers are also confused due to the mistranslation.

Therefore, a thorough analysis of the sentence is required in terms of its background activities, language features and target readers. 


\subsection{Deviation from the Expression Mode of Target Language}

Financial English needs to be expressed in a standardized way due to its professionalism [6]. However, financial English has many terms and complex sentence patterns. Sometimes the author thinks the translation is professional enough, but it is not. It is common in financial English translation that translators misinterpret the meaning of the sentence due to irregular expression mode, thus making it difficult for readers to understand.

Example 8: An experienced work-out unit can provide valuable guidance during initial underwriting and restructures that can help to ensure that the bank's return is maximized in the event of default.

Version 1: 一个经验丰富的工作单位可以在最初的承销和重组过程中提供 有价值的指导, 帮助确保银行在违约情况下的回报最大化。

Version 2: 经验丰富的问题应对部门可以在初始承贷和重组过程中提供有 价值的指导, 帮助确保银行即使在违约情况下也能实现回报最大化。

Analysis: In version 1, the term "work-out" and "underwriting" are mistranslated. And the version 1 is deviated from the expression mode of target language. However, the version 2 effectively conveys the author's message intention and conforms to the expression mode of target language due to its professionalism.

Therefore, in order to solve the problem of conforming to the standards of expression, we should accumulate more encyclopedic knowledge of the target language and get familiar with the expression mode of the target language, so as to achieve the maximum degree of conforming to the target language expression.

\section{Strategies for Improving the Translation Quality of Financial English}

In the previous article, we mentioned three common translation mistakes in financial English. Therefore, in this chapter, the author will put forward corresponding translation strategies aiming at the above three problems.

\subsection{Term Verification}

In the process of financial English translation, the first thing to be solved is the problem of term verification. In the process of verifying terms, there are several aspects in which you can check terms. First, with the help of the financial English dictionary and online corpus, we can make a comparative analysis to verify the specific meaning of terms. Second, through the image search function. When it comes to professional terms that cannot be verified, it can be searched through pictures, and verify the corresponding meanings of the terms through its visual representation. Third, we can use the website and parallel text. When it comes to an uncertain term, we can search the corresponding parallel text through Google to check which translation has been used more frequently, and then we can conduct a comprehensive analysis to confirm the meaning of terms. 


\subsection{Logic Analysis}

In the translation of long financial English sentences, many translation mistakes fail to understand the original author's intention, thus misinterpreting the original author's meaning and resulting in translation mistakes. To solve this problem, translators should firstly grasp the whole content of the sentence from the perspective of context. Secondly, the logical information of the sentence should be analyzed to determine the major and minor information of the sentence. Finally, the translation should be arranged and combined according to the Chinese expression mode, so as to ensure the effectiveness of the translation.

\subsection{Encyclopedic Knowledge Expanding}

When translating financial English sentences, translators often think the translation version is professional enough, but sometimes it is not. According to Sperber and Wilson, conceptual and logical information, encyclopedic information and lexical information in our brains are linked together. Hence, these three kinds of information existing in the audience's cognitive environment constitute the factors that restrict the translator's understanding process [7]. Therefore, in the process of translation, translators should constantly expand their encyclopedic knowledge and bilingual knowledge, thereby improving their ability of expression and making their version more expressive.

\section{Summary}

This paper first introduces the stylistic features of financial English, and then analyzes three common mistakes in financial English, namely, errors of terms, errors of logic analysis and deviation from the expression mode of target language. And then three strategies are being put forward based on the common errors. Therefore, when doing translation practice, translators should first understand the logical structure of the sentence and analyze it carefully. Then translators should use the corresponding expression mode of the target language according to its stylistic features. Finally, translators should pay attention to the accuracy of terms, so as to produce a high-quality translation.

\section{Acknowledgements}

First and foremost, I would like to show my deepest gratitude to my supervisor, Prof. Yuan Sen, a respectable, responsible and resourceful scholar, who has provided me with valuable guidance. Then, I would also like to thank all my classmates and teachers who have offered me some valuable suggestions and develop the fundamental and essential academic competence.

\section{Conflicts of Interest}

The author declares no conflicts of interest regarding the publication of this paper. 


\section{References}

[1] 陈黎峰. 金融英语术语的特点及其翻译 [J]. 上海科技翻译, 2004(1): 24-26.

[2] 陈玉清. 金融专业英语词汇的学习与掌握[J]. 福建金融, 2003(2): 47-48.

[3] 付勇林, 唐跃勤. 科技翻译 [M]. 北京: 外语教学与研究出版社, 2012.

[4] 连淑能. 英汉对比研究[M]. 北京: 高等教育出版社, 1993.

[5] 陈世涁. 金融翻译技法[M]. 北京: 中国对外翻译出版公司, 2002.

[6] Newmark, P.A. (2001) Textbook of Translation. Shanghai Foreign Language Education Press, Shanghai.

[7] 何自然, 苒永平. 关联性: 交际与认知导读 [M]. 北京: 外语教学与研究出版社, 2001. 